\title{
Human Performance Technology The End of an Era
}

\author{
Fred Nickols, CPT
}

$5 / 29 / 2010$

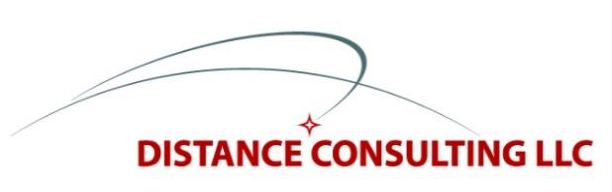

This article appeared in the FORUM section of Human Resources Development Quarterly in 1990. Its central thesis is that the world of work and working has changed in deep and fundamental ways, drawing into question the relevance and the utility of much of what is known as human performance technology. As the subtitle indicates, it is the end of an era. 


\section{Introduction}

For the past 40 years my life at work has revolved around training, programmed instruction, instructional systems, organization development (OD), performance technology, management consulting and, above all else, systems. For many of those years, I earned my living as a consultant, sometimes as an "internal," sometimes as an "external." In one way or another, most of my projects centered on improving performance and productivity.

I believe the era of human performance technology is drawing to an end. In this article, I would like to draw on my experience as a practitioner to make a case for that assertion. Let's begin with how I got started as a practitioner.

\section{The Transition to Civilian Life}

In 1974, as I was readying myself for civilian life after spending almost 20 years in the United States Navy, I was faced with a choice between two career options: "playing it safe," and "going for broke."

On the one hand, as a skilled, experienced fire control technician (FT), familiar with the inner workings of radars, computers, gyroscopes, optical rangefinders, gun mounts, missiles, and other equipment and technology found in modern shipboard weapons systems, I could "play it safe," that is, I could go just about anywhere and find "a good job" as a technician.

On the other hand, since 1969 I had been working in that area of endeavor we now call "Human Resources Development." I'd had a tour of duty involving assignments as a classroom instructor, a programmed instruction writer, and an instructional systems developer. I'd also had a subsequent tour working as an internal organization development (OD) and management consultant in the Navy's Human Resources Management Project.

During the course of my work as an internal OD consultant in the Navy, I learned of what struck me at the time as extraordinary sums of money being paid for consulting services. The lure of "big money" proved irresistible and I settled on my "go for broke" option.

My career as a consultant has been extremely rewarding and just plain fun. I've had ample opportunity to air my views, opinions, likes, dislikes, and even a few ideas. I have published many articles in a wide range of publications, all of which focus on one or another aspect of human performance technology. I've also had ample opportunity to test my ideas. Through it all, I've had but two aims: to master and to advance that body of knowledge known as "Human Performance Technology."

\section{The Tap Root of Performance Technology}

The clear and undeniable home of human performance technology is a professional society that started out as the National Society for Programmed Instruction (NSPI) and is now known as the International Society for Performance Improvement (ISPI). The gurus, the 


\section{Human Performance Technology: The End of An Era}

founders of the field include the likes of Tom Gilbert, Joe Harless, Robert Mager, and Geary Rummler.

In many ways, human performance technology grew out of efforts to determine why training wasn't transferring to the workplace. Programmed instruction was proving that learning had taken place, yet what had been learned wasn't being put into practice back on the job. Investigations of that phenomenon are, in large measure, one of the main roots of performance technology.

But, to my way of thinking, the taproot of human performance technology is the work of none other than Frederick Winslow Taylor. He was the first to make a serious study of work itself, and he was the first to seek systematic ways of improving human performance and of making work itself more productive.

Peter Drucker is fond of pointing out that few of those who criticize Taylor have ever read what Taylor had to say. I took Drucker's admonishment to heart and set out to acquire and read Taylor's published works, all of them, including the two-volume biography of Taylor written by Frank Copley eight years after Taylor's death.

Rounding up a more or less complete set of Taylor's works proved quite a task; it took four years and no small amount of luck, money, and time spent scouring the shelves of stores that carry old, used, and rare books. Suffice it to say that all the cardinal principles of human performance technology can be found in Taylor's writings. Even the supposedly modern concept of feedback is there for all to see.

Pre-eminent among Taylor's precepts is the notion that the person who does the work is ill prepared to improve upon it. Taylor believed that studying work and improving upon it entails a science that far transcends the individual worker's knowledge of a particular skill, task, or job. For Taylor, the work of studying the work of others required special skills and knowledge.

Taylor's view is reflected in the practice of human performance technology in the distinctions made between master performers and performance analysts. It is also reflected in instructional technology in the distinction between subject matter experts (SMEs) and instructional developers. Taylor's precept also shows up in the aptly named field of artificial intelligence (AI) as the distinction drawn between "domain experts" and "knowledge engineers."

Taylor's influence, properly credited or not, is far more pervasive than many know or perhaps care to admit. Nevertheless, with the advent of the human relations school of thought, triggered by Elton Mayo's famous studies at Western Electric's Hawthorne plant, Taylorism or "scientific management," fell quickly into disrepute, where it has remained ever since. Ironically, the human relations school of thought has since joined Taylorism in exile, displaced first by organization development and then by "the systems view." 


\section{A Century of Controlling Behavior}

For almost 100 years, from the time Taylor began his studies at Midvale in 1876, until Peter Drucker published The Age of Discontinuity in 1969, the focus of most managers and industrial engineers was the overt, physical behavior of the worker. This is understandable; most work was of a physical or manual nature.

The end sought was control over the results of the work process. The means used centered on controlling the activity of working. For most, this meant controlling the workers' behavior. For some, the control of others' behavior was and remains an end unto itself.

But in 1969 Drucker pointed out a profound shift in the nature of work itself. It had been and was then still shifting from a materials-base to an information or knowledge base. People were becoming, to use Drucker's term, "knowledge workers." The skills of the head were becoming more important than those of the hands; brain was replacing brawn as the primary factor in labor and in productivity.

By 1980, the shift to knowledge work was more or less complete. Clerical, technical, managerial, and professional workers dominated the work force. Farm workers, once the largest segment of the work force, represented less than three per cent of it, and factory workers represented an ever-diminishing percentage. Moreover, this shift took place in the brief span of 60 years, lightning-fast in comparison to the usual pace of social change.

The most fundamental effect of the shift to knowledge work was its breaking of that centuries-old command, communication, and control device known as "the chain of command." This was an issue in which, as a career military man, I had a more than passing interest. I explored this issue and its implications for human performance technology in an article written several years ago (Nickols, 1983).

The loss of control, or at least a shift in the locus of control, brought about by the shift to knowledge work has occupied the thoughts of many people much more qualified than I.

In 1975, Navy Captain C. E. Bekkedahl explored it eloquently on the pages of the Naval Institute Proceedings, the prestigious publication of the United States Naval Academy. He was drawing attention to the profound effects technology was having on the profession of naval arms and the implications of those effects for military discipline. Numerous scholars grappled with the problem presented by the shift to knowledge work, some of the best known include Daniel Bell of Harvard and David Birch of MIT. And Peter Drucker continued exploring the shift to knowledge work in his books; most thoroughly in Management in 1973, and in several others since.

A brief spate of books appeared, purporting to address knowledge work and knowledge workers, but none seemed to me to fully comprehend or present the problem nor propose any practical solutions. (Dale Zand's 1981 book, Information, Organization, and Power, is one noteworthy exception.) 
The message in most of these books amounts to saying that knowledge workers are different. They're better educated, they hold higher expectations, and they won't put up with the guff tolerated by manual workers. Therefore, you have to treat them differently (and, presumably, better).

In 1970, when I first read The Age of Discontinuity, I was stationed at the Navy's Instructor Training (IT) School in San Diego. I immediately recognized that I was one of these new-fangled "knowledge" workers and, further, that the advent of knowledge workers in large numbers signaled the arrival of momentous opportunity; namely, working on the task of figuring out how to make knowledge work more productive. I also believed that the tools and techniques I had mastered at IT school (e.g., task analysis, performance analysis, and the then-emerging notions of "non-training" problems and non-training solutions such as feedback) were eminently suited for tackling this task.

So, in 1974, I left the Navy and set out to become a consultant and to solve the problem of making knowledge work productive.

Guess what? I don't think it can be done; not in the conventional sense, anyway. I certainly don't think "human performance technology" is the answer. As a matter of fact, I think human performance technology has just about reached the end of the road, if not the end of its rope. The more than 100-year era of relying on external agents to improve the performance and productivity of other people is essentially over. It's finished. Kaput. The target has changed.

To make knowledge work productive requires nothing less than the complete reengineering of those configurations of social, technical, financial, and political factors we call organizations; specifically, those portions of organizations which I refer to as work and work control systems.

Before I tell you why I think this is the case, I think I should tell you something about the events of the past three years, the ones whereby I arrived at my conclusions.

\section{Experiences in the Late 1980s}

In late 1986, I received a call from a friend and colleague, a former Booz-Allen consultant, who was at the time a vice president and the chief of staff for a well-known financial services firm. He had an assignment in mind for me and wanted me to fly to New York City to interview with his boss, the executive vice president of administration.

The assignment was to "clean up" the firm's service center, to make it more productive. My prospective client's business was booming. Revenues were soaring skyward but so were the costs of servicing the products being sold. In short, the business was getting bigger but, except for sheer size, it wasn't getting any more profitable.

Of immediate concern was the recent and rapid expansion in staff and expenses at the service center. If for some reason the business experienced a downturn, profits could dis- 
appear altogether. Then there would be hell to pay. (In October of 1987, the entire stock market took a nose-dive and the devil called his note due and payable.)

The service center in question was a typical information-intensive, mainframe computerbased, clerical and customer service operation. A couple of days spent poking around and I was satisfied it held no surprises and plenty of opportunities for dramatic improvement.

From my perspective, the operation was very similar to a claims processing operation at a Blue Cross-Blue Shield plan, or the Financial Aid Form (FAF) processing operation at Educational Testing Service: data entry, service transactions, lots and lots of cases suspended from automated processing for manual resolution, and numerous "production problems" which resulted, as they so often do, in the systems and operations people pointing their fingers at one another. Plus, there was a ton of paper. It promised to be a snap. I was in for a big surprise!

The first thing to happen was that my assignment changed. A new product was being rolled out and there was some concern that the mainframe systems shop, already buried in the aftermath of previous rollouts, would not be able to meet the due dates.

The chief of staff asked me to lead a project that would have two objectives: 1) to develop the new product support system on a microcomputer, and 2) to coordinate the roll out of the new product with all the affected business functions, legal, actuarial, marketing, service, and systems.

He was of the mind that the ever-increasing power and capability of desktop personal computers spelled the end for many centralized mainframe-based systems. We both saw a degree of speed, flexibility, and low cost in systems development on microcomputers that mainframe-based efforts simply can't match. And, on my part, I saw the potential of microcomputers for extending rather than curtailing the human side of enterprise.

In mid-November of 1986, a small task force of people knowledgeable about the product and the operations necessary to support it was assembled and the work of spelling out the processing requirements for the system to be built began.

On December 1st, the team of three young men who would actually build the system was assembled and they too set to work.

Eighty-nine days later, toward the end of February in 1987, the new product and the new system were rolled out. It was a remarkable accomplishment.

To be sure, the new system was not without its warts and blemishes, and functions not needed immediately remained to be developed, but these "glitches" were remedied as rapidly as they were identified. The project was a success and more than a few were amazed by the speed with which a full-featured life insurance policy administration system had been developed and installed by essentially four people who knew very little about the insurance business and absolutely nothing about the product when they began the project. 
More than a few were also resentful at the manner in which the project had been accomplished. It was rammed down their throats.

This first project was undertaken originally as a backstop or contingency measure in relation to the effort underway in the mainframe systems shop. But, as the project progressed and it became clear that the microcomputer-based system could and would be ready in time, the mainframe effort was dropped and the microcomputer-based system became the mainstream effort.

As a result of the first project's success, it was decided that the next new product to be rolled out would be a microcomputer-based effort from the beginning. The chief of staff's influence was rising and he was able to hire three more people, bringing the total in his "New Ventures" group to six, not counting me, himself, and his administrative assistant.

There was method to our seeming madness. Our ultimate aim of improving the productivity of the service center was in fact well served by our foray into systems development.

In information-intensive, computer-based operations, the computer system determines the skills required of people. What people do and how they do it in such operations is the result of how the work is distributed between people and the computer, and of how the computer-based system is itself configured and constructed.

To approach directly the manual side of operations in the service center without also being able to change the computer system would result in nothing more than "paving the cow paths," that is, in making more efficient work that perhaps should not be done at all. Tactically, then, we were developing computer-based administration systems; strategically, however, we were still going after the larger issue of total service center productivity.

Things were going well. The second project was underway and moving along at a good clip. My contract had been extended through the end of October 1987. My client was satisfied, although he was hinting that, for a full year's engagement, he was wondering if I would consider a slight reduction in my daily fee. However, before we could negotiate new terms for the balance of my engagement, the situation exploded in our faces.

The president of the company where I was working, generally considered a product design genius, had serious differences of opinion with the chairman of the parent company about the future direction of this particular subsidiary. In the middle of 1987, the president resigned to form his own company. Shortly thereafter, several key players resigned to join him, including my client, who took with him two of the three young systems builders.

With the president gone, the parent company's systems shop descended on the subsidiary and gobbled up its systems unit, digesting what it could and spitting out the rest. 
Oddly enough, the parent company made no move on the remnants of the "New Ventures" group my client had established. I thus found myself in the peculiar position of running an organizational unit as a consultant. We had our hands full too. Two new products were being rolled out, one on the mainframe and one on a microcomputer. The atmosphere in which we worked was one of uncertainty, ambiguity, speculation, suspicion, distrust, and downright paranoia. But we kept at it.

When the new president and CEO came on board, I dutifully informed him that, with my original client now gone, I considered my contract null and void and would leave if he so desired. Or, if he preferred, I would stay on until its specified termination. He asked me to stay. He was not well versed in the arcane arts and argot of systems, and he wanted someone who was to be around to advise him; to "translate," if nothing else.

In September of 1987, I reminded the new president that my contract was nearing its end and we began negotiating a second year's contract. Besides being a statesman and a shrewd businessman, the new president was an extremely competent negotiator.

He took me by complete surprise one day when he executed an end run around our consulting contract negotiations and asked me to join the firm. I accepted, and on November 2, 1987, I assumed my new position as senior vice president for systems and operations, a post I held for eighteen months.

My experience as a senior officer, confidante of and consigliere to the CEO, and member of the management committee charged with running the business rounded out and completed my view of the full range of issues associated with improving performance and productivity in a profit-oriented corporate setting. This alone makes that tour of duty invaluable to me.

My point thus far is simply summarized as follows: I have examined the problem of performance and productivity improvement from every conceivable angle: top, bottom, middle, inside and outside, and both ends.

So, let us now turn our attention back to knowledge work, the knowledge worker, and the problem of making knowledge work more productive.

\section{Back to Knowledge Work}

Peter Drucker, in examining the shift to knowledge work, pointed out what is perhaps the key difference between knowledge workers and manual workers: There are few, if any, prefigured work routines facing the knowledge worker. Most work, for knowledge workers, requires them to configure their response to or action in a given situation.

For this reason, Drucker also pointed out that knowledge workers cannot, in the conventional sense, be supervised or controlled, and that only they can make their work more productive. 


\section{Human Performance Technology: The End of An Era}

Consequently, the emphasis of power and authority in our organizations and institutions must, although it has yet to do so, shift from ensuring compliance to seeking contribution. Unfortunately, the pressures to comply and conform are still fierce in corporate America whereas the incentives to contribute are still weak.

By way of example, consider this: A client company, caught in a tremendous cost-crunch, launched an employee suggestion program to identify areas where cost savings could be realized. The incentives were non-economic; employees would receive recognition in the form of a "blurb" in the company newsletter.

I commented that such piddling rewards would likely yield equally piddling recommendations and suggested that employees who could come up with confirmed, hard-dollar savings, be given 10 per cent of the first year's savings. My idea received no consideration whatsoever. The thought of paying people for their ideas was viewed with distaste. There would be no sharing of any savings.

Yet, the aim of managers, executives, and those who advise them, must be one of eliciting and soliciting productive contributions from individuals. It is not enough nor is it any longer possible to engineer, ensure, or enforce compliance with some abstract model of what is all too often nothing more than a mythical master performer.

More important, compliance is in many cases no longer relevant. Routine, repetitive work, performed by armies of regimented workers has all but disappeared in many quarters. What's left is being turned over to machines as fast as analysts and engineers can figure out how to do so, subject only to the constraint of figuring out what to do with the people who used to do it (and that, very often, seems not to be much of a constraint at all).

I am referring here to more than just factory or low-level clerical work. Loan and credit application processing are two higher-level decision-making functions that have already been significantly invaded by algorithmic automation. Insurance underwriters and adjusters are next in line.

So, too, is much of the work of actuaries in what is generally perceived as the creative work of product design, as well as much of the work that goes into the design of automobiles, spacecraft, missiles, and even those tiny little chips that make it all possible. (Read George Gilder's book, Microcosm, for a thoroughly fascinating account of what's going on in computer technology and where it's likely to take us.)

Any and all information-processing work of an unambiguous nature can be subjected to algorithmic definition and subsequently programmed and assigned to a computer. The first pass of algorithmic automation has already swept over the world of work.

The first time around, automation picked up the obvious. The second pass, already underway, is intended to pick up the not so obvious; for example, the "suspense stream," that flow of claims, forms, and applications dropped out of machine-based processing for 
manual review, for people to process. This work will disappear as fast as the necessary algorithms can be fabricated, and they will be fabricated, you can count on that.

And there will be yet a third wave of algorithmic automation, just as soon as the folks in artificial intelligence and elsewhere realize that the aim in performance and productivity improvement has never been one of figuring out what people are doing and how they do it, but, rather, one of figuring out what should be accomplished and then of determining how best to accomplish it.

What will that leave us in the way of work for people to do? Not much. The arts; lots of low-level, almost menial service work; some work involving interactions between and among people; consulting (always a haven and a refuge); maybe some marketing work, although that too, to use Taylor's term, is rapidly being "systematized;" and a few, highly-paid, very demanding and I hope equally rewarding positions for professionals (e.g., accountants, attorneys, dentists, engineers, executives, managers, physicians, perhaps some teachers, and tons and tons of technicians).

Psychologists and psychiatrists will of course be in great demand, but mundane, methodical work will be all but wiped from the face of the earth. (Whatever are we going to do with all those people who once worked for a living?)

Another core aspect of the shift to knowledge work is that the meaningful unit of work has ceased to be the task. It never was the job. Now, for most people, it is the project. And, for most organizations, it is the process. Here too there is an implication for human performance technology: Its focus will surely shift, as it has already begun doing, from individual to group, unit, process and organizational performance.

The challenge is no longer one of making Charley's or Charlotte's or even a bunch of Charleys' and Charlottes' work more productive at the task level. The challenge is now one of making teams, units, processes, and entire organizations productive. One of the key measures used to assess the success of such efforts is known as "unit cost."

The mathematical structure of the unit cost measure is such that the aim of productivity improvement points inexorably toward eliminating the labor component altogether. This means eliminating the work performed by people.

There is no culprit or "bad guy" here, only the harsh realities of economics; specifically, the unrelenting mathematics of the unit cost measure.

\section{Unit Costs and The Mythical Mr. Ishimoto}

Let's suppose I own a factory in which is made that classic little product, the Widget. I make it for $\$ 10.00$ and I sell it for $\$ 12.00$. Of my $\$ 10.00$ in costs, $\$ 5.00$ are attributable to direct (human) labor. Let's suppose further that I'm able to pay the employees who produce these Widgets wages of $\$ 10.00$ per hour. 


\section{Human Performance Technology: The End of An Era}

In this factory, which produces 16,000 Widgets per day, I employ 1,000 people, all of whom put in a full eight-hour day. Working backward through the mathematics, it follows that my factory is producing two Widgets per hour per employee.

But trouble lurks on the horizon, in the direction of the land of the rising sun. There, a certain Mr. Ishimoto has worked out a new method of production. He can produce better Widgets for $\$ 5.00$ and sell them for $\$ 9.00$, a price I can't even come close to, let alone match or beat.

Mr. Ishimoto's company soon penetrates and threatens to dominate a market I once thought was mine. Adding insult to injury, Mr. Ishimoto not only has bigger margins than I do, but he's also paying his workers $\$ 12.50$ per hour, fully 25 per cent more than I pay mine. What the devil is going on here?

Chances are, Mr. Ishimoto's factory is producing several more Widgets per hour per employee than mine produces. Chances are, he's got a more up-to-date, more automated plant, with better quality control and probably fewer employees. Chances are, Mr. Ishimoto paid attention to the likes of Deming, Drucker, Juran and Mr. Taylor. Chances are, he's more determined than I; so are his employees in comparison to mine. In short, Mr. Ishimoto is not only kicking my tail in the marketplace, he's likely to continue doing so.

Why? Simple. His unit costs are lower than mine and his product is better. His shop is more productive than mine. In a freestanding market, I can't compete. So, what do I do?

Chances are, I holler "foul," and complain that Mr. Ishimoto is guilty of "Widget dumping." I might also attribute his successful attack on my business to his use of cheap, offshore labor (but the numbers won't allow me to get away with that excuse.)

Perhaps I could call Senator Harvey Perkins, a long-time friend and the recipient of some sizable campaign contributions, and see if there's any way my old friend Harvey can get his congressional colleagues to hike the import duties on Mr. Ishimoto's Widgets, or establish some quotas, or something. Anything! My plea, of course, is based on the objective of preserving jobs for Americans. But, chances are I won't do anything about the productivity of my plant. Why? Because I've got bigger problems. At least they're bigger to me.

Once I was the happy owner of a family business. Then, 15 years ago, when it hit the magic $\$ 100$ million mark in sales, I took it public. Ever since, I've been up to my neck in the alligators that infest the stockholder swamp. Earnings-per-share are down and the analysts on "the street" haven't touted my company's stock for more than a year. The stock itself has fallen to almost half its former value.

To make matters worse, my company is ripe for a takeover. The 500 acres of land on which my factory sits was purchased for a song 75 years ago by my grandfather and is now worth a small fortune. It is just one of many "hidden assets" on my books. 
The employee pension fund is overfunded and it, too, is ripe for a takeover, or a rip-off, depending on your point of view. JJQ (Jack, Joker, and Queen), an investment banking firm, has concluded it could buy up my business, roll over the pension fund, sell off the assets as well as sell the business itself, and make a tidy little profit.

Not even the "golden parachutes" given to the officers of my company seem likely to deter JJQ (leading my major stockholder to say we should all be given parachutes made of real gold and forced to leap out of a plane). I may have to adopt a "poison pill" defense. Hell, I might have to take one.

Right now, frankly, I'm simply trying to figure out how to keep my company, not to mention my pay, "perks," place, and prestige as its chairman, and CEO. So don't come into my office making noises about improving human performance and productivity unless you can show me how I can quickly, easily, and inexpensively make my entire operation cost-competitive in comparison to Mr. Ishimoto's.

If you can show me how to get my unit costs down, below, or at least close to Mr. Ishimoto's, then I'm all ears. Otherwise, get out and stay out. I'm a very busy man with some very pressing problems, and I don't have time to waste shooting the breeze with people who can't produce clear-cut, bottom line results and who don't understand what business is all about. I need a "home run," dammit! Singles won't do.

On the other hand, I stand to walk away from the buy-out with many millions of dollars. $\mathrm{Hmm}$.

\section{Ethics and Economics}

Ethics and economics make strange bedfellows, which accounts no doubt for the fact that they are rarely found in bed together. Our inability to integrate the ethics and economics of productivity improvement is proving to be our undoing in this country.

Again, it was Frederick Taylor who first focused on the problem of cutting up the productivity improvement pie. He observed that management and labor, instead of focusing on how to increase the "size of the surplus," engaged in continuous bickering over how much each would receive. They argued over how to divide what they had instead of collaborating in getting more for both.

What Taylor proposed was increasing the "size of the surplus" (his term for profits) through productivity improvement and the subsequent sharing of that increase by both management and labor.

Contrary to common belief, Taylor did not have as an objective the aim of making workers work harder. Indeed, except insofar as was necessary to study the work itself his focus wasn't the worker. Taylor focused primarily on the work itself and the tools used to do it. He actually sought to make working life better and better paying for most workers. Far 
too many people were unnecessarily killing themselves through arduous, inefficient, ineffective work practices, and for pittance wages.

In the hypothetical Widget factory described earlier, Taylor would argue that the aim should be one of increasing wages while decreasing labor costs. There are those who believe this can't be done. Now, as in Taylor's time, there are people who still confuse wages with labor costs; they believe that if wages go up so must labor costs. Not so.

Consider once again the hypothetical Widget factory. At a production rate of two Widgets per hour per person and a direct labor cost of $\$ 10.00$ an hour, the cost of the direct labor component in each Widget is $\$ 5.00$. These are our benchmark figures.

Now, let's suppose that, at the end of a successful productivity improvement effort, the factory could produce 10 Widgets per employee per hour. Let's suppose further that the workers were now being paid $\$ 20.00$ an hour. This "sharing of the surplus" represents a 100 per cent increase in wages (from $\$ 10.00$ to $\$ 20.00$ per hour) and a 250 per cent reduction in direct labor unit costs (from $\$ 5.00$ per Widget to $\$ 2.00$ per Widget). Let's also suppose that this effort slashed the non-labor unit costs in half, from $\$ 5.00$ to $\$ 2.50$. The total unit costs would then be at $\$ 4.50$ and the competition with Mr. Ishimoto would begin to heat up.

But, paragons are inevitably followed by epigones, and Taylor was no exception. Those who followed him were not in the service of his dream of harmonious relations between workers and the management and their sharing of a larger surplus. Those who followed Taylor were in the service of the captains of industry, whose only concern was getting a bigger slice of the pie they already had.

The aim of "holding the watch" on the worker long ago shifted from obtaining before and after benchmarks (Taylor's version of the pre-test and post-test) to one of pressuring the workers to pick up the pace and produce more for the same or lower wages. When successful, which it often was, this approach resulted in the management realizing all the increase in the size of the surplus.

Not much has changed since Taylor's time. Management still seeks to realize all the gain and only begrudgingly bestows wage hikes upon the worker. "Soldiering," Taylor's term for the silent conspiracy of workers to restrict output and to maintain like levels of productivity among themselves, is still practiced, and at some surprisingly high levels. And management and labor still feud over how much of the existing pie each will receive instead of collaborating in baking a bigger one.

\section{Summing It Up}

What I have learned after 40 years of practicing my craft can be summed up as follows:

No one gives a damn about improving productivity, least of all human productivity. And the economics of unit costs are such that the aim is not simply one of reducing the labor 
component of unit costs, but one of eliminating it altogether, whenever and wherever possible.

As a result, many productivity improvement efforts are typically seen for what they truly are, efforts whereby workers will be expected and perhaps enabled to produce more but, proportionally, to earn less. The costs of labor continue to be confused with wages, and countless opportunities for real and sizable improvements in performance and productivity go begging hat in hand.

Most of the work performed by human beings that is readily amenable to appreciable improvement via sophisticated training or applications of performance technology has disappeared or is disappearing, replaced by machines or by knowledge work, which is devilishly difficult to get at using methods and techniques originally intended for use with manual work.

Even when we succeed in pinning down and documenting knowledge work, especially of the clerical or quasi-clerical variety, it is then generally capable of being carried out by a computer, which creates a problem much bigger than the one of improving human productivity; namely, What do we do with the people?

Most important, the agents of management (e.g., trainers, performance technologists, and work design-redesign specialists) can no longer engineer the performance or the productivity of knowledge work at the level of individual tasks. Remember: knowledge work must be configured not prefigured.

It is the day-to-day stuff of leading people, not of managing them or their work, that really affects productivity; it's the hand-holding, the encouraging, the going to bat for people, and the sharing of the hardships, the risk, the recognition, and the rewards that tempts people to contribute and sustains them as they strive for excellence. These leadership behaviors must themselves be configured not prefigured. In other words, conformity at the executive level is as deadly as compliance at the working level.

To sum it up, the era of compliance has ended, and with it has ended the dream of engineering individual human performance. The era of individual contribution has just begun and we don't even have a vocabulary suited to discuss the issue let alone formulate decisions and then carry them out.

\section{Where To From Here?}

So, what will happen? Where do human performance technologists go from here?

Well, one remaining trick in the performance technologist's bag is to help knowledge workers create better methods and better tools. For many knowledge workers in the information age, this means better hardware and better software.

There is also a tremendous need for greatly improved technical training and education. Hundreds of thousands of engineers and technicians will be needed to create, operate, 
maintain, and repair the machinery of our brave new world. One of our roots will take some of us back to technical training and education.

There is an equally tremendous need for greatly improved productivity but it is the productivity of complex, social-technical, financial-political, human-machine work systems, not simply the productivity of individual workers. The task of engineering these total work systems will address all the aforementioned factors, not just the conventional "socio-technical" ones. And, make no mistake about it - Democracy is on its way into the workplace.

One of our roots will take some of us toward the improvement of total work system performance and productivity, and toward the democratization of the work place.

But efforts to engineer individual human performance and productivity in the world of work and working, except for a comparatively small percentage of the population, will soon cease to matter. Perhaps it already has.

\section{Bibliography}

1. Bekkedahl, C. E., "Discipline and The Profession of Naval Arms." Naval Institute Proceedings. United States Naval Academy: 1975.

2. Copley, Frank B., Frederick W. Taylor. Harper \& Brothers: 1923.

3. Drucker, Peter F., The Age of Discontinuity. Harper \& Row: 1969.

4. , Management. Harper \& Row: 1973.

5. Gilder, George, Microcosm. Simon \& Schuster: 1989.

6. Nickols, Frederick W., "What Is in the World of Work and Working," Performance \& Instruction Journal: Oct, 1983.

7. Taylor, Frederick W., "Testimony before the Special House of Representatives Committee," in Scientific Management. Harper \& Brothers: 1947.

8. _ "On the Art of Cutting Metals," in Scientific Management," Clarence B. Thompson (Ed). Harvard University Press: 1914.

9. , The Principles of Scientific Management. Harper \& Brothers:

1911.

10. , Shop Management. Harper \& Brothers: 1911.

11. Tofler, Alvin, Future Shock. Random House: 1970.

12. Zand, Dale E., Information, Organization, and Power. McGraw-Hill: 1981.

\section{Contact the Author}

Fred Nickols can be reached by e-mail at fred@nickols.us. Other articles of his can be found on the article section of his web site at http://www.nickols.us/articles.html. 